\title{
NEGOSIASI RUANG PUBLIK: MODERNISASI DAN PENGUATAN CIVIL SOCIETY MODEL PESANTREN
}

\author{
Saifudin Asrori \\ Fakultas Ilmu Sosial dan Ilmu Politik, \\ Jl. Kertamukti Pisangan, Ciputat, Tangerang Selatan \\ Emial: saifudin.asrori@uinjkt.ac.id
}

\begin{abstract}
Negotiating Public Sphere; Modernity and Civil Society in Pesantren. Although the contribution of pesanten in socio-economic development has been widely recognized, this Islamic educational institutions are oftenassociated as intolerant and militant education which became the root of radical movements and terrorism in Indonesia. This article attempts to answer the ability of pesantren to prepare its students to be able to participate in modern society and support civil society. The role of pesantren are evaluated through educational programs relating to anti-violence education, interfaith and ethnic tolerance, pluralism, human rights, gender equality, democracy, and political and social justice. Based on an ethnographic study in Pondok Modern Gontor, this article is a portrait that boarding schools have taken the role of progressive politics and the emergence of an active role in strengthening civil society in Indonesia.
\end{abstract}

Keywords: Public Shepre, Modernity, Civil society, Pondok Modern Gontor

Abstrak: Negosiasi Ruang Publik; Modernisasi dan Penguatan Civil Society Model Pesantren. Meski kontribusi pesantren dalam pembangunan sosial-ekonomi telah banyak diakui berbagai kalangan, lembaga pendidikan Islam ini seringkali diasosiasikan sebagai lembaga yang mempromosikan pendidikan yang intoleran dan militan yang kemudian menjadi akar gerakan radikal dan terorisme di Indonesia. Artikel ini mencoba menjawab kemampuan pesantren dalam mempersiapkan santrinya agar mampu berpartisipasi di era masyarakat modern dan mendukung penguatanmasyarakat sipil. Peran pesantren di era modernisasi dievaluasi melalui program-program pendidikan yang berhubungan dengan pendidikan anti-kekerasan, toleransi antar keyakinan dan etnis, pluralisme, Hak Asasi Manusia (HAM), kesetaraan gender, demokrasi, serta keadilan politik dan sosial. Berdasarkan studi etnografi di Pondok Modern Gontor, artikel ini mengambarkan bahwa pesantren telah mengambil peran politik progresif dan berperan aktif dalam penguatan munculnya masyarakat sipil di Indonesia.

Kata kunci: Ruang Publik Modernitas, Masyarakat Sipil, Pondok Modern Gontor 


\section{Pendahuluan}

Meski kontribusi pesantren dalam pembangunan sosial-ekonomi telah diakui berbagai kalangan, lembaga pendidikan Islam ini seringkali diasosiasikan sebagai lembaga yang mempromosikan pendidikan intoleran dan militan yang kemudian menjadi akar gerakan radikal dan terorisme di Indonesia. Berita BBC misalnya ketika mengomentari aksi bom Bali, menyebutkan:"salah satu jawaban terletak pada perguruan Islam atau pesantren, mengajarkan dokrin dan pendidikan islam yang keras". ${ }^{1}$ Selain itu, Badan Nasional Penanggulangan Teroris (BNPT) juga mengindikasi 19 (sembilan belas) pesantren yang mendukung gerakan radikalisme dan terorisme. ${ }^{2}$ Lembaga anti teror ini juga merekomendasikan pemberian 'sertifikasi ulama', berdasarkan pertimbangan adanya keterkaitan antara ajaran pendidikan jihad yang diajarkan oleh kyai/ulama di pesantren.

Berbagai tuduhan dan streotype terhadap pendidikan islam di pesantren hendaknya difahami dalam konteks perubahan sosial akibat pengaruh modernisasi dan globalisasi. Aksi radikal dan teror yang melibatkan kalangan pesantren merupakan salah satu bentuk negosiasi atas kondisi ruang publik yang berlawanan dengan apa yang dicita-citakan. Dalam kondisi ini, arus modernisasi mengurangi peran agama dalam sektor publik menjadi urusan pribadi, biasanya berbentuk marjinalisasi dan penurunan peran agama. Maka apabila modernisasi difahami sebagai marjinalisasi agama, maka pengajaran dan pendidikan di pesantren dapat diklasifikasikan sebagai anti-modern. Implikasi lainnya adalah pendidikan model pesantren tidak mampu untuk mengakomodasi perubahan ilmu pengetahuan dan tekonologi atau memberikan penguatan terhadap pluralitas dan demokratisasi dalam ruang publik.

Pengalaman Indonesia jelas menunjukkan kenyataan sebaliknya. Pesantren telah memberi kontribusi sangat berarti dalam penyelenggaraan pendidikan Islam dan pada gilirannya pembentukan identas sosial-politik kaum Muslimin. ${ }^{3}$ Di lembaga pendidikan inilah proses pembelajaran Islam berlangsung, di mana kaum Muslim diperkenalkan dengan ajaran-ajaran

\footnotetext{
${ }^{1} \mathrm{http}: / /$ www.bbc.com/indonesia/berita_indonesia/2012/10/121011_keluarga_bombali.shtml

2 http://www.cnnindonesia.com/nasional/20160203201841-20-108711/bnpt-19-pesantrenterindikasi-ajarkan-radikalisme

3 Karel A. Steenbrink, Pesantren, Madrasah, dan Sekolah: Pendidikan Islam dalam Kurun Modern, (Jakarta: LP3ES, 1986). h. 6.
} 
Islam sehingga menjadi bagian dari praktik kehidupan mereka. Pada awal abad ke-20, masa-masa awal tumbuhnya kesadaran sebagai bangsa, pesantren berfungsi sebagai basis pembentukan dan diseminasi gagasan Islam tradisional. ${ }^{4}$ Dan, lembaga pendidikan Islam ini pula yang kemudian menjadi salah satu basis penting pembentukan kaum santri pada 1950-an. Peran serupa juga bisa dilihat pada perkembangan 1970 hingga 1980-an, ketika proses modernisasi oleh pemerintah Orde Baru telah berpengaruh sangat kuat dalam kehidupan Muslim. Kebangkitan kelompok Muslim yang disebut "kelas menengah santri baru" — yang mengetengahkan gerakan Islam kultural, menggantikan Islam politik oleh santri lama pada 1950-an-berlangsung sejalan dengan modernisasi yang terjadi dalam lembaga pendidikan Islam tradisional pesantren di Indonesia.

Dengan mengikuti Cassanova artikel ini berasumsi bahwa tidak semua ekpresi keagaamaan bertentangan dengan penguatan masyarakat sipil dan perusak struktur demokrasi. ${ }^{6}$ Lebih dari itu, masih banyak kemungkinan-kemuningkinan pelibatan agama dalam kehidupan publik. Kajian Lukens-Bull (2005) berjudul Peaceful Jihad membahas tentang proses modernitas dalam tubuh umat Islam Indonesia, khususnya di Jawa Timur, untuk kemudian menjadikan 'keisalaman' mereka mempunyai keunikan tersendiri dalam berbagai hal. Lukens-Bull fokus pada dinamika yang terjadi pada sekolah-sekolah Islam di Jawa Timur dikenal sebagai pesantren tentang bagaimana para guru Islam dan pemimpin dalam pesantren itu menggabungkan politik dan simbol-budaya ke dalam kurikulum pesantren. ${ }^{7}$ Proses penggabungan merupakan upaya untuk melampaui pendekatan dekotomis reformis versus tradisionalis dalam Islam yang kemudian diistilahkan dengan "Peaceful Jihad" merupakan prakarsa pesantren dalam menolak gerakan-gerakan Jemaah Islamiyah (JI) atau Laskar Jihad dengan kerangka tradisi budaya Sufi, sebagai benteng pertahanan pesantren dalam masyarakat pesantren Jawa Timur. Artikel ini fokus pada upaya-upaya Pondok Modern Gontor dalam menyiapkan

${ }^{4}$ Taufik Abdullah, Islam dan Masyarakat: Pantulan Sejarah Indonesia, (Jakarta: LP3ES, 1987), h. 152 .

5 M. Syafi'i Anwar, Pemikiran dan Aksi Islam Indonesia: Sebuah Kajian Politik Tentang Cendekiawan Muslim Orde Baru. (Jakarta: Paramadina, 1995). h. 7.

${ }^{6} \mathrm{~J}$. Casanova, Public religions in the modern world. (University of Chicago Press,2011), h.11

Ronald Lukens-Bull, Negotiating Identity and Modernity in Muslim Java (Palgrave Macmillan, 2005). 
santri-santrinya dapat berperan dalam masyarakat modern dan mampu menjadi penyangga penguatan masyarakat sipil di Indonesia. ${ }^{8}$

\section{PM Gontor, Totalitas Cara dan Tujuan Pengelolaan Pendidikan}

Berbagai upaya dilakukan pesantren, termasuk PM Gontor dalam menghadapi realitas perubahan. Slogan, "al-muhâfazhatu 'ala al-qadîm al-shâlih wa al-akhdzu bi al-jadîd al-ashla $\underline{\text { h }}$ (memelihara tradisi lama yang baik dan mengambil inovasi baru yang lebih baik), diterjemahkan sebagai strategi proteksi dan proyeksi. Strategi proteksi dimaksudkan untuk mempertahankan kualitas luhur yang dimiliki oleh para santri dengan cara melindunginya dari pengaruh negatif lingkungan. Kualitas luhur ini, dalam dunia pesantren, dengan sendirinya meliputi kualitas keimanan (kecerdasan spiritual), kualitas keilmuan (kecerdasan intelektual), dan kualitas amaliah (kecerdasan emosional). Sedangkan, strategi proyeksi mencakup langkahlangkah perencanaan, pembangunan, dan pengembangan segenap potensi yang dimiliki oleh para santri melalui dua pendekatan sekaligus: pendekatan individual dan institusional. Pada tingkat individual, strategi ini mengacu kepada pembangunan dan pengembangan aneka minat dan bakat individu para santri dalam berbagai dimensi kecerdasannya, baik spiritual, intelektual, maupun emosional. Pada tingkat kelembagaan, strategi ini mengacu kepada penguatan dan pengembangan kemampuan kelembagaan pesantren mencapai tujuan pendidikannya, dengan tetap berpijak pada visi dan misi, jiwa, orientasi, serta falsafah dan motto pendidikan dan pengajarannya. ${ }^{9}$ Berpijak kepada kedua strategi tersebut, Pondok Gontor tetap survive dan terus berkembang. Saat ini, PM Gontor memiliki santri \pm 15.182 orang dan guru sebanyak \pm 1.884 orang, dengan cabang yang tersebar di beberapa daerah di Tanah Air; di Jawa Timur, Jawa Tengah, Lampung, Sulawesi Tenggara, Poso, Padang, Jambi dan Aceh.

Dalam menjalankan aktivitas pendidikannya, PM Gontor berpijak pada nilai-nilai prilaku kehidupan yang dapat dibedakan menjadi dua, yaitu: nilai esensial dan nilai instrumental serta implementasinya dengan

\footnotetext{
${ }^{8}$ Mengenai gontor dapat kunjungi laman https://gontor.ac.id/

9 Abdullah Syukri Zarkasyi, "Sistem Pendidikan Pondok Pesantren: Pengalaman Pondok Modern Darussalam Gontor." Makalah disampaikan dalam Seminar tentang "Refleksi dan Rekonstruksi Pendidikan Islam,” diselenggarakan oleh Yayasan al-Kautsar, 31 Oktober 2002, di Jakarta Design Center.
} 
disiplin. Kedua nilai tersebut, dipresentasikan dalam Pancajiwa dan Motto Pondok. Rumusan Pancajiwa adalah: (1) keikhlasan; (2) kesederhanaan; (3) berdikari; (4) ukhuwwah islamiyah; dan (5) kebebasan. Sedangkan Motto Pondok yaitu: (1) Berbudi Tinggi; (2) Berbadan Sehat; (3) Berpengetahuan Luas; (4) Berpikiran Bebas. ${ }^{10}$ Sedangkan nilai-nilai instrumental merupakan nilai yang dikontruksi dari abstraksi berbagai konsep, pemikiran, dan motto para pendiri pesantren. Spektrum nilai-nilai tersebut terakumulasi menjadi falsafah dan motto kelembagaan, falsafah dan motto kependidikan, dan falsafah dan motto pembelajaran, orientasi, dan sintesis. ${ }^{11}$

Atas dasar nilai-nilai tersebut, pendidikan di PM Gontor dilakukan melalui totalisas cara dan tujuan. Pendidikan sebagai totalitas cara, adalah penciptaan lingkungan pendidikan, sehingga apa yang dilihat, didengar, dirasakan, dialami, maupun dikerjakan sehari-hari, harus mengandung unsur pendidikan. Hal ini menyiratkan bahwa semua langkah manajemen kepemimpinan dan pengorganisasian kehidupan di Pondok, juga dilakukan dengan melibatkan "kata sepakat" dari semua stake holder di dalam pondok sendiri; dari mulai santri, wali santri, para guru (para keluarganya), para mitra kerja Pondok, dan para Kiai (keluarganya), yang disetujui bukan hanya pada level kebijakan kiai tersebut, tetapi juga dari keteladanannya. Adapun pendidikan sebagai totalitas tujuan, berarti bahwa berbagai kegiatan dan gerakan di PM Gontor itu diarahkan untuk membina kecerdasan santri dengan segala dimensinya, baik kecerdasan spiritual, kecerdasan intelektual, maupun kecerdasan emosional. ${ }^{12}$

Maka paradigma ini mengisyaratkan bahwa proses mengelola pendidikan dan pengajaran, pembiayaan, sarana dan prasarana, serta peningkatan SDM, melibatkan guru dan santri serta semua keluarga Pondok baik sebagai subjek maupun objek dari manajemen. Ini karena tujuannya bukan semata-mata sebagai suatu proses yang terpisah, melainkan terintegrasi dengan strategi pendidikan itu sendiri. Maka dalam kerangka

${ }_{10}$ Penjelasan tentang nilai-nilai tersebut dapat dibaca dalam Tim Penyusun, K.H. Imam Zarkasyi Dari Gontor Merintis Pondok Modern, (Ponorogo: Trimurti Press, 1996); Tim Penyusun, K.H. Imam Zarakasyi Di Mata Umat, (Ponorogo: Trimurti Press, 1996); Pondok Modern Darussalam Gontor, Sejarah Balai Pendidikan Pondok modern Gontor, Penggal I, h. 19

${ }^{11}$ Syukri Zarkasyi, Abdullah. Gontor \& Pembaruan Pendidikan Pesantren. Jakarta: PT Raja Grafindo Persada. 2005, h. 7

12 Syukri Zarkasyi, "Mewujudkan Sekolah Islam Internasional: Sumbangan Pemikiran dari Pengalaman Pondok Modern Darussalam Gontor”. Jakarta, April 2002. 
paradigmatik yang sama, strategi kontrol mutu, penerapan program jangka pendek, menengah, maupun panjang, peningkatan akuntabilitas dan transpransi, dan sebagainya merupakan sarana bagi pendidikan itu sendiri. Hal ini barangkali selaras dengan semboyan pendidikan seumur hidup, "long life education".

\section{Hidup dan Belajar di PM Gontor}

Aktivitas pendidikan dan pengajaran di PM Gontor diselenggarakan oleh beberapa lembaga yaitu Badan Wakaf, sebuah badan legislatif yang bertanggungjawab penuh terhadap pelaksanaan dan perkembangan di PM Gontor, mengamanatkan kepada Pimpinan Pondok sebagai mandatarisnya untuk menjamin keberlangsungan proses pendidikan dan pengajarannya. Sedangkan lembaga yang menanggani secara langsung pendidikan dan pengajaran yaitu Pengasuhan Santri dan Kulliyyatul Mu'allimin alIslamiyyah (KMI). Kedua lembaga tersebut dipimpin langsung oleh Pimpinan Pondok dengan pelaksanaan hariannya, dinamakan "Pengasuhan Santri” dan Direktur KMI.

\section{Pengasuhan Santri}

Kehidupan santri di PM Gontor diatur oleh lembaga Pengasuhan santri adalah lembaga yang mendidik dan membina langsung seluruh kegiatan ekstra-kurikuler santri, atau seluruh aktifitas kehidupan santri di Pondok Modern Darussalam Gontor (PMDG) di luar jam belajar santri di KMI, mulai bangun tidur sampai tidur kembali. Secara struktural, lembaga ini ditangani langsung oleh Pengasuh Santri yang juga Pimpinan Pondok. Dalam menjalankan tugasnya hariannya, lembaga ini dibantu oleh beberapa orang staf. Tugas Pengasuhan Santri ini dapat digolongkan menjadi beberapa hal, yaitu selain sebagai supervisi kegiatan seluruh santri, juga bertindak sebagai pembina, pembimbing dan penyuluh OPPM dan Koordinator Gerakan Pramuka.

Kehidupan santri Gontor selama 24 jam tidak lepas dari disiplin yang selalu didasari oleh nilai-nilai dan ajaran-ajaran kepondok-modernan. Pengendalian disiplin santri, tidak hanya aspek organisasinya saja, tetapi segala aspek, yang terlingkup dalam ubudiyah, akhlak, belajar, etos kerja, berbahasa Arab-Inggris, pakaian, absensi, dan sebagainya. Dalam menegakkan disiplin santri, sistem kepengasuhan di PMDG lebih me- 
nekankan pada kesadaran preventif dan meminimalisir hukuman fisik. Dengan demikian, jalannya disiplin santri menjadi lebih baik dan suasana kekeluargaan lebih tampak. Terkait dengan sistem pembinaan, ada beberapa hal yang menjadi strategi pembinaan, yang tidak saja ditujukan kepada santri, tetapi kepada siapa saja yang bernaung dalam lingkungan kampus, yakni seperti dalam tabel berikut: ${ }^{13}$

\begin{tabular}{crl}
\hline NO & SISTEM & \multicolumn{1}{c}{ STRATEGI } \\
\hline 1 & Keteladanan & $\begin{array}{l}\text { Penonjolan sikap teladan dari para kyai, guru, pengasuh, dan } \\
\text { santri. }\end{array}$ \\
\hline 2 & $\begin{array}{l}\text { Penciptaan } \\
\text { lingkungan }\end{array}$ & $\begin{array}{l}\text { Semua yang dilihat, didengar, dirasakan, dikerjakan, dan } \\
\text { dialami sehari-hari harus mengandung unsur pendidikan. }\end{array}$ \\
\hline 3 & Pengarahan & $\begin{array}{l}\text { Kegiatan-kegiatan diawali dengan pengarahan terutama } \\
\text { tentang nilai-nilai pendidikan yang terkandung di dalamnya. }\end{array}$ \\
\hline 4 & Pembiasaan & $\begin{array}{l}\text { Menjalankan program-program pendidikan dari yang ringan } \\
\text { ke yang berat dengan disiplin tinggi. Terkadang pemaksaan } \\
\text { juga diperlukan. }\end{array}$ \\
\hline 5 & Penugasan & $\begin{array}{l}\text { Pelibatan dalam penyelenggaraan kegiatan-kegiatan } \\
\text { kependidikan }\end{array}$ \\
\hline
\end{tabular}

Dalam upaya menjaga berjalannya strategi, efektivitas dan efisiensi pembinaan, Lembaga Pengasuhan dibantu oleh beberapa tim khusus, yaitu lembaga musyrif (pembimbing), seperti, Musyrif Rayon/Asrama, Musyrif Pelajaran Sore, Musyrif Konsulat para santri, Musyrif Muhadharah dan Diskusi, dan Musyrif Bahasa. Di lain pihak lembaga ini juga ikut membantu menyelesaikan problemetika yang dihadapi santri. Baik secara langsung maupun tidak langsung, dengan melalui guru wali kelas atau para musyrif yang dibentuk tersebut.

Sebagai lembaga pembimbing santri, ada beberapa aspek kegiatan yang dikerjakan baik secara harian dan minguan, bulanan mupun tahunan oleh lembaga ini. Secara harian-mingguan, seperti misalnya, mengadakan evaluasi kerja mingguan bagi Ketua-ketua bagian OPPM dan Koordinator Pramuka, mengadakan Tauizyah Dîniyah di Masjid Jami’ setiap hari Selasa dan Kamis, diisi oleh Pimpinan PMDG dan guru-guru senior dengan materi yang

\footnotetext{
${ }^{13}$ Syukri Zarkasyi, Abdullah. Gontor \& Pembaruan Pendidikan Pesantren, h. 10
} 
variatif, menyusun jadwal dan seleksi ujian imâmah dan khatib shalat jum'at bagi kelas VI di Masjid Jami', serta ujian dan praktik imâmah pengurus asrama yang dilaksanakan di kamar-kamar siswa, berkoordinasi dengan staf KMI dalam penanganan pendidikan dan pengajaran santri, memberikan bimbingan dan penyuluhan bagi santri-santri yang mempunyai masalah dan memeriksa laporan absensi santri dari kelas I sampai kelas VI setiap malam pukul 22.00 WIB. Selain sifatnya harian, masih ada kegiatan yang menjadi rutinitas Lembaga Pengasuhan ini secara bulanan dan tahunan.

Pada kegiatan bulanan ini, sifatnya tertuju kepada program-program supervisi dan evaluasi, seperti menghadiri rapat koordinasi antar bagianbagian OPPM untuk menciptakan harmonisasi baik intra maupun antar personil bagian; mengadakan pertemuan dengan seluruh pengurus OPPM dan pengurus asrama; mengadakan pertemuan dengan para musyrif bagian kegiatan ekstra-kurikuler; mengadakan pertemuan dengan Guru-guru Wali Kelas untuk membahas masalah kepribadian dan ubudiyah santri; memeriksa laporan keuangan dan kegiatan bulanan bagian-bagian OPPM, rayon, konsulat dan organisasi-organisasi bahasa.

Sedangan untuk kegiatan Tengah Tahun atau Tahunan, bagian ini juga menangani pembentukan panitia penjemputan santri setelah liburan di terminal Ponorogo dan di stasiun kereta api Madiun, dengan bantuan siswa kelas VI; pengecatan dan perbaikan sarana dan prasarana Pondok, distribusi buku "Diktat Khutbatul 'Arsy dalam Pekan Perkenalan di Kulliyatul Mu'allimin al-Islamiyah Pondok Modern Gontor" kepada seluruh santri baru; dan buku Serba Serbi Singkat tentang Pondok Modern Gontor; Diktat Pekan Perkenalan Tingkat Lanjutan untuk kelas V; penulisan raport mental siswa kelas I-V setiap semester, membimbing kepanitiaan bulan Ramadhan dengan segala kegiatannya, seperti pembinaan dan bimbingan belajar para mukimin calon pelajar PMDG, pelaksanaan shalat tarawih dan kuliah subuh di masjid Jami' dan kegiatan-kegiatan ibadah lainnya di bulan Ramadhan, pembimbingan kepanitiaan bulan Syawwal dengan segala kegiatannya, seperti: penerimaan siswa baru, penjemputan siswa lama, pembagian asrama bagi siswa lama, pelayanan tamu dengan menyediakan café- café dan kantin-kantin yang dikelola sendiri oleh siswa kelas VI, dan memaksimalkan sistem keamanan dengan mendirikan tenda-tenda di sekitar wilayah kampus yang strategis.

Selain itu tugas yang diemban oleh staf pengasuhan ini terkait dengan kepanitiaan hari-hari besar Islam seperti; membentuk Panitia Qurban untuk mengkoordinir guru-guru dan santri-santri yang ingin melaksanakan 
udhhiyah (Qurban). Daging qurban ini dibagikan kepada masyarakat desa-desa binaan Pondok, para simpatisan Pondok, para pekerja Pondok, penduduk desa sekitar, guru-guru senior, dan seluruh santri; Peringatan hari besar Islam dengan berbagai kegiatan perlombaannya, dan lain-lain. Untuk menjamin keasrian wilayah kampus, juga disupervisi oleh lembaga ini, yaitu dengan menanam beberapa pohon peneduh dan mendesain taman-taman dalam kampus. Adapun pekerjanya adalah para santri sendiri (Kelas III intensif, IV, V dan VI), yang tergabung dalam kelompok "Basatino", sebuah istilah yang diadopsi dari bahasa Arab; artinya taman.

Di lain pihak, ada hal yang lebih penting dalam sistem kepengawasan staf pengasuhan santri ini, yaitu membimbing kepanitiaan Pekan Perkenalan (Khutbatul Arsy) dengan segala rangkaian kegiatannya: seperti, pengajaran "Hymne Oh Pondokku", pelatihan baris berbaris menghadapi Apel Tahunan, pelaksanaan Pekan Olahraga dan Seni, pelaksanaan Lomba antar rayon/asrama, pelaksanaan Jambore dan Raimuna, perlombaan Cerdas-Cermat, perlombaan senam antar rayon, perlombaan Vokal Group antar rayon, perlombaan drama antar rayon, perlombaan baris berbaris (PBB) antar rayon, penyelenggaraan Apel Tahunan Pondok Modern, Pelaksanaan Kuliah Umum tentang Kepondok Modernan (Khutbatul Arsy), penyelenggaraan Demonstrasi Bahasa dari seluruh daerah yang ada di Indonesia serta bahasa asing, penyelenggaraan Malam Aneka Ria Nusantara, penyelenggaraan Festival Lagu dan Poetry Reading, pelaksanaan Laporan Panitia Bulan Syawwal, pelaksanaan Serah Terima Amanat dari panitia Bulan Syawwal kepada pengurus OPPM, penyelenggaraan Pentas Seni Didasa (Siswa Darussalam) Band, pembagian hadiah dari rangkaian kegiatan di atas, Pergelaran Drama Arena siswa kelas V, Pergelaran Pentas Seni Mahadasah, dan Pergelaran Panggung Gembira siswa kelas VI.

Kegiatan Apel Tahunan 'Khutbatul Arsy" dilakukan dengan tujuan untuk mengenalkan kepada santri kehidupan di PMDG secara menyeluruh. Terkait dengan cara pandang terhadap Gontor, para pendirinya sangat menekankan agar jangan memandang secara setengah-setengah, lantaran pertama, kepercayaan orang tua yang sudah dititipkan kepada lembaga pesantren untuk mendidik anaknya, menuntut adanya keikhlasan dalam belajar, yang sepenuhnya diamanahkan kepada pengelola pesantren. Kedua, untuk mendukung penciptaan lingkungan Proses Belajar-Mengajar (PBM) yang kondusif, rasa kepercayaan tersebut harus dikelola dengan totalitas. Dua hal di atas, memerlukan sistem yang menjadi objek vital dalam PBM 
peserta didik dalam sebuah pesantren. Sistem tersebut bersifat total, dan mengikuti setiap sunnah disiplin yang sudah terbina sejak lama tersebut.

Selain kegiatan di atas, Pengasuhan santri juga mencakup pemberian pelajaran Sore dikhususkan untuk siswa KMI kelas I-IV dan dibantu oleh bagian Pengajaran OPPM. Kegiatan yang berlangsung pada pukul $13.50-$ 14.50 WIB. Kegiatan ini merupakan aktifitas ko-kurikuler bagi siswa KMI, untuk pendalaman materi akademik, meliputi: Muthalaah, Nahwu, Sharf, Reading, dan Al-Qur'an. Selain pendalaman materi, kegiatan ini dilakukan untuk memberi kesempatan kepada siswa kelas VI untuk melatih diri dalam mengajar di kelas.

Karena itu, kegiatan harian pelajaran sore ini dilakukan oleh santri senior yang dikoordinir oleh Bagian Pengajaran dan diawasi oleh Musyrif Pelajaran Sore. Program kerja harian bagian pelajaran ini mirip dengan staf KMI, yaitu menciptakan suasana yang kondusif dengan melakukan gerakan tabkîr (datang tepat waktu), pemeriksaan idâd (persiapan mengajar), dan naqdu al-tadrîs (evaluasi mengajar), termasuk melakukan kontroling kelas dan asrama siswa oleh piket keliling.

Selain kegiatan harian, ada kegiatan mingguan untuk peningkatan pelajaran sore, diantaranya; (1) pertemuan rutin guru koordinator Pelajaran Sore bersama seluruh pengurus bagian Pengajaran OPPM. Pertemuan ini dilakukan untuk memantapkan pelaksanaan kegiatan Pendidikan Belajar Mengajar (PBM) pada kegiatan tersebut; (2) evaluasi mingguan untuk para pengajar dan pertemuan para ketua kelas I-IV yang diadakan di kantor pengurus Bagian Pengajaran.

Sebagai salah satu proses PBM, pada Pelajaran Sore juga dilaksanakan evaluasi belajar, yaitu berupa Ujian Pertengahan Tahun (UPT) dan Ujian Akhir Tahun (UAT), yakni mirip dengan sistem ujian di KMI. Pelaksanaan UPT diawali dengan pengarahan untuk seluruh siswa kelas VI oleh Direktur KMI di Masjid Jami' Gontor. UPT terbagi menjadi dua ujian yaitu imtihâan syafahi (ujian lisan), imtihâan tahrîri (ujian tulisan) dan imtihân lughah (ujian bahasa). Materi-materi ujian pertama adalah alQur'an, Tajwid,'Ibadah Amaliyah dan Qauliyah, yang hanya diikuti oleh seluruh kelas 1, kelas 1 intensif dan kelas 2 dari siswa baru, sedangkan para pengujinya adalah kelas VI yang dibantu oleh guru-guru yunior.

Sedangkan imtihâan tahrîri (ujian tulisan) terbagi menjadi dua gelombang, yaitu ujian semua materi yang diikuti oleh siswa kelas I-IV, 
yang diawasi oleh guru dan dibantu oleh siswa kelas VI, serta imtihâan lughah (ujian bahasa) sebagai program Pondok yang ditangani langsung oleh Language Advisory Council, sebuah lembaga Musyrif bahasa, dengan bantuan Bagian Penggerak Bahasa OPPM. Materi bahasa ini adalah ujian seluruh kosa kata (vocabulary) dan kalimat (idiom) yang diberikan setiap pagi oleh bagian pengerak bahasa asrama. Ujian Akhir Tahun juga dilaksanakan tak jauh berbeda dengan ujian pertengahan tahun ini.

Namun di akhir tahun, Pelajaran Sore, yang merupakan kegiatan kokurikuler, juga mempunyai raport tersendiri, yang disebut sebagai raport mental. Penulisan Raport Mental bukan saja berisikan nilai pelajaran sore tetapi juga nilai hasil pantauan terhadap perkembangan mental santri Gontor selama ditangani oleh wali kelas, para pengurus rayon, beberapa bagian OPPM dan Gerakan Pramuka. Penilaiannya meliputi nilai mental, kepramukaan, latihan pidato, serta kemampuan berbahasa Arab dan Inggris. Raport Mental tersebut dibagikan kepada santri pada liburan pertengahan tahun dan akhir tahun sebagai laporan pengasuhan kepada orang tua/wali santri yang juga harus ditandatangani oleh orang tua siswa.

\section{Sistem Kulliyatul Mu'allimin al-Islamiyah (KMI)}

Kulliyatul Mu'allimin al-Islamiyah (KMI) adalah lembaga yang mengurus aktivitas akademis para santri, dimana sistem perjenjangannya sudah diterapkan sejak tahun 1936. Sistem perjenjangan tersebut terdiri dari program reguler dan intensif. Program reguler untuk lulusan Sekolah Dasar/Madrasah Ibtida'iyah, dengan masa belajar 6 tahun, yakni ditempuh secara berurutan dari kelas 1-6. Jika mengikuti standar pendidikan nasional, kelas I-II-III di KMI, setingkat SLTP/MTs. Adapun kelas IV-V-VI, setingkat SLTA/MA. Program intensif di KMI untuk lulusan SMP atau MTs dan di atasnya, ditempuh selama 4 tahun, yakni dengan urutan jenjang kelas kelas 1-3-5-6. Kelas intensif ini sebenarnya hanya diselenggarakan pada kelas 1 dan 3, karena itu disebut sebagai kelas 1 intensif dan 3 intensif. Sedangkan di kelas 5 mereka akan belajar secara reguler besama-sama dengan lulusan SD/MI yang sudah duduk di kelas 5 .

Dalam melakukan kegiatannya, KMI memiliki bagian-bagian, yatu: Bagian Proses Belajar-Mengajar (PBM), Bagian Penelitian dan Pengembangan (Litbang) Kurikulum, Bagian Karir Guru, Perpustakaan, Tata Usaha dan Peralatan (inventaris). KMI bertanggungjawab atas, kegiatan belajar-mengajar 
santri. Kegiatan KMI dapat dibagi menjadi kegiatan harian, mingguan dan tahunan. Pelaksanaan semua kegiatan tersebut selalu mengacu pada perencanaan, pelaksanaan, supervisi maupun evaluasi. Pertama, kegiatan harian yang meliputi; gerakan tabkîr, taftîsyu al-idâd, naqdu al-tadrîs, kontrol kelas, dan at-ta'allum al-muwajjah. Gerakan takbîr adalah gerakan masuk kelas tepat waktu. Kegiatan ini dilakukan oleh staf KMI dengan cara mengontrol siswa ke asrama, dapur, dan tempat-tempat keberadaan santri di Pondok agar dapat masuk kelas dengan segera. Siswa yang terlambat akan dicatat, menjadi pertimbangan dalam menilai sikap mental mereka, dan siswa tersebut dapat diberikan sanksi. Taftîsyu al-idâd adalah pemeriksaan persiapan mengajar guru pada buku idâd (persiapan) khusus, yang dilakukan oleh guru-guru senior. Pembuatan idâd ini wajib dilakukan oleh para guru. Guru yang tidak membuatnya tidak diizinkan mengajar. Sedangkan naqdu al-tadriss, yakni evaluasi (kritik) mengajar. Sebagai pesantren yang memiliki sistem dan metodologi tersendiri, terutama dalam kurikulum Bahasa Arab dan Dirasah Islamiyah, Gontor perlu melestarikan sistem dan metodologi tersebut, sedangakan naqdu al-tadris, dalam hal ini merupakan salah satu cara peningkatan kedua mutu tersebut. Guru senior, baik yang memiliki jam mengajar pada hari itu maupun yang tidak, sudah dijadwal rolling di tiaptiap kelas untuk memastikan kegiatan ini berlangsung. Apabila ditemukan kesalahan dalam mengunakan metode ajar, guru yang bersangkutan akan diberi bimbingan. Dengan cara demikian, sistem Gontor dapat dipertahankan dan dikembangkan menjadi lebih baik. Lebih dari itu, selain adanya pengawasan (supervisi) seperti yang diterangkan di atas, ada juga sistem supervisi di kelas dan asrama di tengah berlangsungnya jam pelajaran. Model kedua ini dilakukan untuk mengantisipasi terjadinya kelas kosong, keterlambatan guru dalam mengajar, dan untuk memastikan legalitas atau tanda keterangan tidak masuk kelas--dalam istilahnya disebut tashrîh—bagi santri, baik karena alasan menjadi piket asrama maupun karena sedang sakit.

Kedua, kegiatan mingguan dan bulanan. Kegiatan mingguan ini ditujukan untuk guru dan siswa. Untuk guru, diadakan pertemuan mingguan bersama Pimpinan Pondok dan Direktur KMI, biasanya dilakukan pada hari kamis (di Gontor dikenal dengan istilah Kemisan). Selain sebagai media penyamaan persepsi, tujuan pertemuan tersebut adalah untuk menyampaikan informasi penting mengenai kegiatan Pondok dan perkembangannya. Lebih dari itu juga dilakukan evaluasi kegiatan belajar-mengajar selama satu minggu. Adapun untuk siswa, staf KMI mengkoordinir ketua-ketua kelas berkumpul, 
untuk menyampaikan informasi program-program KMI, dan mendengarkan laporan para ketua kelas, terkait dengan keadaan siswa dan keadaan kelas. Kemudian pada setiap bulannya, ketua kelas dilibatkan KMI untuk mengecek batas-batas pelajaran, dengan memberikan buku khusus pengecekan pelajaran dari bagian PBM yang akan dilaporkan oleh masing-masing ketua kelas, pada setiap akhir bulan. Tak jarang pula, pada setiap minggu dan bulan, para guru pengajar materi pelajaran tertentu memberian evaluasi belajar, yang dinamakan murâjảah al-durûs. Model ujian ini diadakan untuk menciptakan lingkungan belajar yang kondusif, memacu pencapaian target pengajaran guru, dan mendongkrak motivasi belajar siswa; suatu hal yang cukup lama direalisasikan di Indonesia, sebelum adanya sistem Kurikulum Berbasis Kompetensi (KBK).

Ketiga, kegiatan tengah tahunan, yaitu ulangan umum, yang terbagai dalam ujian pertengahan tahun dan ujian akhir tahun. Pada pertengahan tahun pertama, ujian ini diikuti oleh seluruh siswa dari kelas I-1V. Setiap hari diujikan 3 buah mata pelajaran, dengan durasi waktu 90 menit. Pada pertengahan tahun kedua, ulangan umum diadakan sebelum ujian praktik mengajar (al-tarbiyah al-amaliyah) untuk siswa kelas VI), yang diikuti oleh kelas I-IV KMI. Materi yang diujikan adalah Dirasah Islamiyah, dan beberapa materi yang dianggap berat oleh siswa dari hasil evaluasi dan supervisi para guru pengajar dan wali kelas. Sedang model ujian kedua, diawali dengan pelaksanaan ujian syafahi (ujian lisan). Materi yang diujikan adalah AlQur'an, yang meliputi (Tajwid, Ibadah Amaliyah, Ibadah Qauliyah, dan doa); Bahasa Arab, meliputi Muhadatsah, Muthala’ah, Nahwu, Sharaf, Mahfudzat, Mufradat, Tarjamah, dan Balaghah (khusus untuk kelas V); dan Bahasa Ingrris (Conversation, Reading, Grammar, Vocabulary, Translation dan Dictation). Model ujian akhir tahun juga sama persis dengan ujian pertengahan tahun.

Keempat, kegiatan tahunan. Kegiatan ini meliputi penerimaan siswa baru, penataran guru baru, dan yudisium kenaikan kelas V. Sejak awal berdirinya Gontor, penerimaan siswa baru dilakukan melalui sekali ujian masuk, yaitu pada tanggal 11 Syawwal atau 10 hari usai hari raya Idul Fitri. Namun sejak dibukanya Pondok Gontor 2 (tahun 1996), ujian masuk KMI dilaksanakan dua gelombang. Materi ujian terdiri dari ujian lisan (Al-Qur'an, Praktik Ibadah, dan Psikotes) dan ujian tulisan (Berhitung Angka, Berhitung Soal, Bahasa Indonesia, dan Imla'). Sedangkan untuk penataran guru, ditujukan untuk guru baru (santri kelas VI yang baru tamat dari KMI). Materi dalam penataran ini mencakup petunjuk dan pedoman mengajar dalam paket, seperti Al-Qur'an dan Imla', Ilmu Keguruan dan Strategi Belajar-Mengajar, Profesi 
Guru dan Keguruan di PMDG, Tujuan Instruksional tiap-tiap Mata Pelajaran, Bimmbingan dan Konseling serta Evaluasi Hasil Belajar. Semua materi tersebut disampaikan oleh guru senior KMI Gontor.

Kegiatan penataran guru baru ini dilaksanakan untuk mereka yang terpilih menjadi guru KMI Gontor saja. Akan tetapi, menjelang 1 tahun kelulusannya, para santri akhir secara keseluruhan sudah dibekali dengan berbagai macam kegiatan khusus menyangkut penyelenggaraan PBM yang cukup ketat. Seperti misalnya, mereka dikarantinakan, dengan tujuan agar dapat mengintensifkan proses belajar menghadapi ujian akhir tahun, dimana semua materi kelas I-V akan diujikan. Sistem belajar bersama ini juga diselenggarakan agar membangkitkan rasa persaudaraan dan kebersamaan yang kuat untuk mereka. Hingga proses disiplin lari pagi dan senam bersama bahkan kegiatan ringan lainnya, seperti pementasan seni sekalipun dilakukan secara kolektif. Selain prestasi akademis, akhlak, sikap dan mental juga diperhatikan dalam kegiatan ini. Hal lain yang menjadi program kelulusan santri kelas VI ini adalah at-tarbiyah al-'amaliyah atau praktik mengajar, al-rihlah al-iqtishâdiyah (economic study tour), dan pembekalan wawasan berbagai persoalan.

Selain itu, masih ada beberapa program lain yang lebih spesifik dicanangkan KMI untuk peningkatan kemampuan akademis siswa. Antara lain, Fathul Kutub, Fathul Mu’jam, Manasik Haji, Penulisan Karya Ilmiyah, Tarbiyah al-'amaliyah, Economic Study Tour (rihlah iqtishâdiyah), dan pembekalan wawasan menjelang tamat belajar di KMI. "Fathul Kutub" adalah latihan membaca kitab (terutama kitab klasik), yakni sebagai wahana melatih dan menguji kemampuan siswa dalam bahasa Arab. Santri diberi tugas untuk membahas persoalan-persoalan tertentu dalam bidang Aqidah, Fiqih, Hadis, Tafsir, Akhlak, dan lain-lain. Para santri diwajibkan menyerahkan laporan tertulis mengenai hasil kajiannya kepada guru pembimbing. Kegiatan ini dilakukan secara kolektif, yang berlangsung selama satu minggu, dan ditujukan untuk santri kelas V dan VI. "Fathul Mu'jam" adalah latihan dan ujian membuka kamus yang berbahasa Arab untuk kelas V, terutama dalam menelusuri akar dan makna kosa kata. Akan tetapi program ini sudah dipelajari sebelumnya pada kelas IV dan III intensif, yaitu menjadi bagian parsial yang dibimbing oleh wali kelasnya. Akan tetapi pada kelas V, dilaksanakan lazimnya model Fathul Kutub, dilakukan secara kolektif selama satu minggu. "Manasik Haji" adalah latihan praktik ibadah haji. Berlokasi di dalam kampus, program ini ditujukan untuk santri baru, 
sebagai praktik pelajaran fiqih dasar yang sudah diatur dalam silabus KMI. Kegiatan ini tentunya dibimbing oleh guru-guru yang sudah menunaikan ibadah haji dan guru materi pelajaran fiqih.

Al-Tarbiyah al-'amaliyah, atau praktik mengajar, dilakukan dengan pembagian kelompok yang dibimbing oleh guru-guru senior. Kegiatan ini ditujukan khusus siswa kelas IV, yang dilakukan sebelum ujian tulis. Tujuannya tak lain untuk meningkatkan kualitas dan keterampilan mengajar. Al-Rihlah Iqthishâdiyah, adalah studi untuk mengetahui tentang dunia usaha dan kewiraswataan. Kegiatan ini diselenggarakan untuk membekali dan menanamkan jiwa kewiraswastaan. Materimateri disampaikan dengan metode ceramah dan demonstrasi, dengan mengunjungi secara langsung objek usaha yang tersebar di Pulau Jawa. Pembekalan wawasan untuk siswa kelas VI, menjelang tamat belajar di KMI. Mereka dibekali dengan berbagai macam wawasan, yang meliputi orientasi tentang pers dan jurnalistik, strategi belajar di perguruan tinggi, wawasan pengembagan kemasyarakatan, kepesantrenan, kepustakaan dan perpustakaan, Studi Islam, metode dakwah, ceramah dan dialog mengenai madzâhib al-haddmah (madzhab sesat), kursus computer.

\section{Pembahasan}

Penanaman nilai-nilai modern di PM Gontor menjadi bagian integral dalam proses pendidikan dan pengajaran di pondok pesantren. Sejak pertama kali berdiri, Gontor menamakan dirinya sebagai Pondok Modern yaitu mengintegrasikan dua sistem pendidikan sekaligus, sistem pendidikan pesantren dengan sistem pendidikan modern. Idealisme, jiwa, dan falasafah hidup berikut sistem asramanya tetap mengacu kepada khazanah dunia pesantren, tetapi penyalenggaraannya dilakukan secara efektif dan efisien yang menjadi kekhasan sistem pendidikan modern. Konsekwensi dari integrasi ini adalah bahwa seluruh kegiatan santri; baik di dalam maupun di luar kelas merupakan kegiatan-kegiatan pendidikan.

Proses penanaman nilai dilakukan melalui keteledanan, merupakan metode pendidikan yang efektif dan efisien. Penanaman nilai-nilai keikhlasan, perjuangan, pengorbanan, kesungguhan, kesederhanaan, tanggung jawab, dan lainnya akan lebih mudah dan tepat sasaran dengan pemberian keteladanan. Penanaman nilai-nilai semacam di atas tidak bisa hanya dilakukan melalui pengarahan, pengajaran, diskusi, dan sejenisnya, 
karena hal tersebut lebih menyangkut masalah perilaku, bukan sematamata masalah keilmuan.

Penanaman nilai keikhlasan ini dipilih karena ia merupakan asas utama dari seluruh proses pendidikan di Pondok. Karena, keikhlasan menempati urutan pertama dari kelima Jiwa Pondok; keikhlasan, kesederhanaan, kemandirian, ukhuwwah islamiyah, dan jiwa bebas. Keikhlasan adalah pangkal dari seluruh jiwa Pondok lainnya. Jiwa sederhana, mandiri, ukhuwwah, dan jiwa bebas harus didasari oleh keikhlasan yang mendalam, agar jiwa-jiwa itu menjadi benar-benar bermakna di hadapan Allah SWT. Segala sesuatu dilakukan dengan niat semata-mata ibadah, li Allâh, ikhlâs hanya untuk Allah SWT. Kyai ikhlas dalam mendidik, santri ikhlas dididik dan mendidik diri sendiri, dan para pembantu kyai ikhlas dalam membantu menjalankan proses pendidikan. Jiwa ini menciptakan suasana kehidupan pondok yang harmonis antara kyai yang disegani dan santri yang taat, cinta, dan penuh hormat. Jiwa ini menjadikan para santri senantiasa siap berjuang di jalan Allah, di mana pun dan kapan pun.

Jika diperhatikan dalam sejarah perkembangan Pondok Gontor, keteladanan di bidang keikhlasan itu benar-benar terlihat dalam segala gerak dan perbuatan para Pengasuh. Di bidang material, misalnya, hingga usia Pondok 10 tahun, Pondok tidak pernah menarik sepeser pun uang sekolah dari santrinya. Segalanya dipenuhi oleh pengasuh. Dari dulu sampai saat ini para Kyai Pimpinan Pondok tidak pernah menerima gaji dari Pondok, mereka malah banyak berkorban untuk Pondok. Keteladanan dalam hal keikhlasan juga dilakukan melalui pewakafan Pondok oleh para pendirinya pada 28 R. Awwal 1378/12 Oktober 1958. Sejak saat itu, para pendiri telah melepaskan kepemilikan pribadinya atas Pondok. Dengan pewakafan itu seluruh keturunan para pendiri tidak berhak lagi atas harta wakaf tersebut. K.H. Imam Zarkasyi menjelaskan bahwa semua saja harus benar-benar memahami pewakafan ini, terutama anak-anak para wakif sendiri: anak cucunya, anak cucu Pak Sahal, anak cucu Pak Fannani. Ia kemudian berkata:

"Kalau seandainya anak saya nanti tidak atau kurang mengakui lepas tanggalnya hak-hak milik ini, sehingga merasa punya dan tetap akan menguasai karena keturunannya ini, berarti tidak mengesahkan wakaf ayahnya, atau membatalkan amal jariyah ayahnya. Kepada anak-anak saya, anak Timurti kami nasehatkan, untuk tidak bertindak atau merasa demikian, karena itu berarti tidak mengesahkan wakaf orang tuanya. Kasihanilah orang tuamu." 
Para pengurus menjadi teladan dalam pendidikan keikhlasan. Mereka ikhlas meluangkan waktu, pikiran, dan tenaganya untuk mengurusi organisasi atau apa saja yang diamanatkan kepada mereka. Mereka tidak ada yang menerima gaji dari Pondok. Para Kyai Pimpinan Pondok tidak menerima gaji karena kedudukannya, direktur KMI dan ketua-ketua lembaga yang lain juga tidak digaji karena jabatan mereka, para guru yang mengelola unit-unit usaha juga demikian. Tidak ada tunjangan jabatan Kyai, tunjangan jabatan direktur, tunjangan jabatan ketua lembaga, dan seterusnya. Demikian pula para pengurus di tingkatan santri; baik OPPM maupun Gerakan Pramuka juga tidak ada yang menerima imbalan materi karena posisi yang mereka duduki.

Selain itu, penanaman nilai demokrasi misalnya, diajarkan melalui proses beroraganisasi. Kegiatan berorganisasi ini merupakan kegiatan yang tak terpisahkan dari kehidupan santri sehari-hari, sebab berorganisasi di Pondok ini berarti pendidikan untuk mengurus diri sendiri (self management). Di dalam asrama, santri diajar untuk bertanggungjawab terhadap dirinya sendiri, KH. Imam Zarkasyi berpesan:

"Setiap datang pelajar baru, berarti bertambah anggota yang turut serta bertanggungjawab terhadap kebersamaan Pondok. Pembayaran yang diambil itu hanya sebagai iuran untuk Pondok dan sekolah, bukan berarti sebagai sewa atau upah. Uang itu kemudian digunakan untuk kepentingan dalam pondok, seperti memperbaiki pondokan yang telah didirikan sebelumnya oleh santri-santri terdahulu. Inilah yang dimaksud zelf berdruiping systeem, artinya sama-sama membayar iuran, sama-sama memakai". ${ }^{14}$

Secara struktural organisasi asrama ini berada di bawah OPPM (Organisasi Pelajar Pondok Modern) yang merupaan pengurus pusat kegiatan santri. Jika OPPM ditangani oleh santri kelas VI, organisasi asrama ini diurus oleh santri kelas $\mathrm{V}$ dengan dibantu oleh santri-santri di kelas bawahnya (kelas IV dan III). Pelaksana OPPM adalah santri-santri kelas akhir (kelas VI) yang terpilih secara demokratis. ${ }^{15}$ Pemilihan Ketua

${ }_{14}$ Tim Penyusun, K.H. Imam Zarkasyi Dari Gontor Merintis Pondok Modern, (Ponorogo: Trimurti Press, 1996)

15 Proses pemilihan berlangsung sebagai berikut: (1) Seluruh santri kelas V yang berasal dari kelas reguler, bukan intensif di tiap konsulat berhak menjadi kandidat. Selanjutnya kandidat tersebut dipilih oleh seluruh anggota konsulat, termasuk santri kelas VI. (2) Dua kandidat peraih 
dan Pengurus Organisasi ini diadakan setahun sekali. Pada setiap akhir masa jabatan, pengurus organisasi ini melaporkan kegiatan-kegiatan yang telah dilaksanakan selama setahun di depan seluruh santri dan guru-guru serta pimpinan-pimpinan lembaga dan Pimpinan Pondok. Seusai laporan pertanggungjawaban diadakan serah terima jabatan dari pengurus lama ke pengurus baru terpilih. Setelah meletakkan masa pengurusannya, mantan pengurus dari siswa akhir tersebut kembali menjadi santri biasa.

Kemudian pendidikan toleransi, di Pondok Gontor melekat pada proses Penempatan santri di asrama-asrama tidak bersifat permanen, maksudnya santri tidak menetap satu kamar, atau satu asrama, selama dia hidup di pesantren, sebagaimana yang umum terjadi di pesantrenpesantren lain. Setiap tahun dilakukan perpindahan asrama, santri pindah dari satu asrama ke lainnya, dan setiap satu semester diadakan perpindahan kamar dalam satu asrama. Hal ini memberikan variasi dalam kehidupan santri. Ini juga bermanfaat agar santri-santri mengenal lebih banyak kawan dan mengetahui berbagai tradisi dan budaya dari santri-santri lain secara lebih luas. Penempatan santri tidak didasarkan pada daerah asal atau suku mereka seperti pada umumnya di pesantren-pesantren lain. Bahkan penempatan ini diusahakan secara maksimal memperkecil kemungkinan santri-santri dari daerah tertentu menempati satu kamar bersama. Ketentuannya, tidak boleh ada lebih dari 3 orang santri yang berasal dari satu daerah menempati satu kamar yang sama. Ini di antaranya untuk melebur semangat kedaerahan ke dalam semangat yang lebih universal. ${ }^{16}$ Di samping itu santri juga belajar mengenai kehidupan bermasyarakat yang lebih luas, berskala nasional, bahkan internasional dengan adanya santri-santri yang berasal dari mancanegara.

Antara santri baru dan lama ditempatkan di tempat yang berbeda. Santri baru menempati asrama khusus untuk santri baru. Pemilihan

suara terbanyak maju untuk ke pemilihan lebih lanjut yang menentukan formatur, terdiri dari 6-10 orang. (3) Formatur tersebut kemudian memilih di antara mereka yang diajukan untuk ikut dalam setiap konsulat, kemudian mengajukan 2 orang yang akan duduk sebagai pengurus OPPM, berasal dari utusan tiap-tiap konsulat yang dipilih oleh anggota konsulat. (4) Para utusan terpilih itu kemudian memilih di antara mereka formatur yang akan menentukan ketua dan susunan pengurus selengkapnya. (5) Susunan pengurus yang dirancang itu dikonsultasikan ke wali kelas dan staf Pembantu Pengasuhan Santri, terakhir dikonsultasikan ke Pimpinan Pondok.

16 Hal ini tidak berarti menafikan unsur daerah. Unsur daerah telah diakomodasi dalam organisasi daerah yang disebut konsulat, yang sudah punya aturannya, tetapi organisasi ini tidak boleh menjadi sumber fanatisme. 
pengurusnya pun melalui seleksi ketat. Karena mereka inilah yang bertanggungjawab langsung membina kehidupan santri baru itu, dari pagi sampai pagi lagi, selain jam-jam masuk kelas. Merekalah yang pertama kali mengenalkan kehidupan Pondok dengan segala dinamika. Segalanya harus dilakukan dengan prima agar prosesnya kemudian benar-benar lancar. Ada pepatah yang sering disampaikan mengenai hal ini "well begun is half done" (permulaan yang baik itu setengah pekerjaan).

Penempatan santri di asrama dibagi menjadi dua kategori, santri kibâr (besar/dewasa) dan santri sighâr (kecil/anak-anak). Pengklasifikasian ini didasarkan pada postur tubuh dan juga usia. Biasanya, tamatan SD digolongkan pada Sighar, dan tamatan SMP ke atas masuk golongan Kibar, tetapi terkadang ada juga tamatan SMP yang ditempatkan di asrama Sighar. Santri Kibar menempat unit-unit asrama untuk Kibar, demikian pula santri Sighar. Ini untuk memudahkan proses pendidikan mengingat adanya perbedaan dalam pendekatan untuk mendidik pada usia yang berbeda itu. Pengaturan model ini juga memberikan kesempatan lebar untuk melatih dedikasi dan loyalitas kehidupan antar santri sendiri dan merupakan bagian dari proses pelatihan kecakapan intelektual, mental attitude, spiritual dan sosial, sekalgius merupakan proses kaderisasi kepemimpinan.

\section{Penutup}

Keseluruhan paparan pada bab-bab sebelumnya dapat kemudian disimpulkan bahwa: (1) Nilai-nilai yang dikembangkan Pondok Gontor dalam membentuk karakter santrinya terdiri dari lima nilai yang disebut dengan pancajiwa pondok, kelima nilai itu adalah keikhlasan, kesederhanaan, kemandirian, persaudaraan yang dilandasi oleh semangat agama, dan kebebasan. Di samping itu Pondok Gontor juga mengembangkan motto seperti: berbudi tinggi, berbadan sehat, berpengetahuan luas, dan berpikiran bebas; (2) Nilai-nilai modern tersebut diimplementasikan baik dalam proses pembelajaran, pembentukan budaya pesantren, kegiatan kokurikuler, dan kegiatan ekstrakurikuler. Karena itu, dapat dikatakan bahwa Pondok Gontor merupakan institusi pendidikan keagamaan yang menerapkan pendidikan karakter secara terpadu dalam keseluruhan proses pendidikannya mulai dari proses pembelajaran, manajemen pesantren, dan kegiatan keseharian santri. 


\section{Pustaka Acuan}

Abdullah, Taufik, Islam dan Masyarakat: Pantulan Sejarah Indonesia, Jakarta: LP3ES, 1987

Anwar, M. Syafi'i, Pemikiran dan Aksi Islam Indonesia: Sebuah Kajian Politik Tentang Cendekiawan Muslim Orde Baru. Jakarta: Paramadina, 1995.

Casanova, J., Public religions in the modern world, University of Chicago Press, 2011

Lukens-Bull, Ronald, Negotiating Identity and Modernity in Muslim Java, Palgrave Macmillan, 2005.

Pondok Modern Darussalam Gontor, Sejarah Balai Pendidikan Pondok modern Gontor, Penggal I, h. 1. , K.H. Imam Zarakasyi Di Mata Umat, Ponorogo: Trimurti Press, 1996

Steenbrink, Karel A., Pesantren, Madrasah, dan Sekolah: Pendidikan Islam dalam Kurun Modern, Jakarta: LP3ES, 1986.

Syukri Zarkasyi, Abdullah, "Mewujudkan Sekolah Islam Internasional: Sumbangan Pemikiran dari Pengalaman Pondok Modern Darussalam Gontor”. Jakarta, April 2002. , "Sistem Pendidikan Pondok Pesantren: Pengalaman Pondok Modern Darussalam Gontor." Makalah disampaikan dalam Seminar tentang "Refleksi dan Rekonstruksi Pendidikan Islam," diselenggarakan oleh Yayasan al-Kautsar, 31 Oktober 2002, di Jakarta Design Center. , Gontor \& Pembaruan Pendidikan Pesantren. Jakarta: PT Raja Grafindo Persada. 2005.

Tim Penyusun, K.H. Imam Zarkasyi Dari Gontor Merintis Pondok Modern, Ponorogo: Trimurti Press, 1996.

\section{Website}

http://www.bbc.com/indonesia/berita_indonesia/2012/10/121011_keluarga_ bombali.sml

http://www.cnnindonesia.com/nasional/20160203201841-20-108711/bnpt19pesantren-terindikasi-ajarkan-radikalisme https://gontor.ac.id/ 